\title{
Inhibition of Clostridium botulinum and its toxins by probiotic bacteria and their metabolites:
}

\section{An update review}

\begin{abstract}
Adel Mirza Alizadeh', Fataneh Hashempour-Baltork², Mahmood Alizadeh-Sani ${ }^{3}$, Mohammad Maleki ${ }^{4}$, Maryam Azizi-Lalabadi ${ }^{5}$, Kianoush Khosravi-Darani ${ }^{2, *}$

${ }^{1}$ Student Research Committee, Department of Food Science and Technology, National Nutrition and Food Technology Research Institute, Faculty of Nutrition Science and Food Technology, Shahid Beheshti University of Medical Sciences, Tehran; ${ }^{2}$ Department of Food Science and Technology, National Nutrition and Food Technology Research Institute, Faculty of Nutrition Science and Food Technology, Shahid Beheshti University of Medical Sciences, Tehran, Iran; ${ }^{3}$ Division of Food safety and hygiene, Environmental health department, School of public health, Tehran University of medical sciences, Tehran, Iran; ${ }^{4}$ Department of Food Hygiene and Aquaculture, Ferdowsi University of Mashhad, Mashhad, Iran; ${ }^{5}$ Research Center for Environmental Deteriminants of Health (RCEDH), Kermanshah University of Medical Sciences, Kermanshah, Iran
\end{abstract}

Correspondending Author: Kianoush Khosravi-Darani, National Nutrition and Food Technology Research Institute, Tehran, Iran. Email: k.khosravi@sbmu.ac.ir

Received: 7 October 2020; Accepted: 8 December 2020; Published: 30 December 2020

(C) 2020 Codon Publications

OPEN ACCESS (c) (i) (ㄱ) ()

REVIEW ARTICLE

\begin{abstract}
Clostridium (C.) botulinum is the causative agent of foodborne poisoning such as botulism, which includes high mortality rates in animals and humans. Probiotic bacteria play critically functional roles in food matrices, as well as agricultural, clinical and nutritional fields. In this review, potentials of various probiotic bacteria and their metabolites to prevent $C$. botulinum toxicity are reviewed. For this purpose, an introduction about $C$. botulinum and its mechanisms of action is provided. After a short introduction of probiotic bacteria and their beneficial health effects on humans, the bacterial mechanisms of their action are reviewed. Then bacteriocin production by probiotic bacteria is described. After description of $C$. botulinum and its neurotoxins, effects of probiotic bacteria on C. botulinum are reviewed with a special focus on effects of the bacterial bacteriocins on this pathogen. Furthermore, physicochemical factors, which show great effects on potential of nisin to prevent growth and toxin production of the bacteria, are introduced. This study has shown that probiotic bacteria and their bacteriocins can be effective on growth, toxin formation and toxicity of $C$. botulinum. In conclusion, probiotic use in food safety studies can be effective in preventing or treating toxicity of $C$. botulinum.
\end{abstract}

Keywords: bacteriocins; decontamination; prevention; probiotic bacteria

\section{Introduction}

Digestive system includes critical roles in digestion and absorption of foods for the production of energy. The gastrointestinal mucosa, which covers a wide surface, is exposed to pathogens and non-pathogen agents (Donaldson et al., 2016). Microorganisms present in the gastrointestinal tract (GIT), especially Lactobacillus spp. and Bifidobacterium spp., play important roles in health (Sadrizadeh et al., 2018; Zendeboodi et al., 2020). These microorganisms include the greatest effects on immune system function, leading to development of a strong balanced immune system (Butel, 2014; Eslami et al., 2020; Soccol et al., 2010). Because the largest and most complex part of the immune system is associated with the tissues of the GIT, therefore, revival immune 
system plays a serious role in protecting humans against various pathogens (Khaneghah et al., 2020). If balance of gut microbiota (microorganisms that usually colonize the body) changes due to the use of various drugs such as antibiotics, it can increase the risk of various infectious diseases by adaptable pathogens such as Clostridium spp. (Bäckhed et al., 2012; Sánchez et al., 2017). Clostridium spp. are Gram-positive, obligate anaerobe endospore-producer bacteria. These bacteria are known as foodborne pathogenic and spoilage bacteria, hazardous to human health (Fooda, 2018). The most important species of this genus include Clostridium botulinum (causing botulism), Clostridium difficile (causing diarrhea during antibiotic therapy) and Clostridium perfringens (causing food poisoning to cellulitis and gas gangrene) (Fooda, 2018). In fact, C. botulinum leads to toxin production. Botulism disease affects various individuals, especially infants (transmitted through honey), causing several complications such as paralysis, nausea, vomiting, abdominal cramps, difficult swallowing or speaking, weak cry, irritability, drooping eyelids, tiredness and difficult sucking or feeding (Fooda, 2018). Naturally, C. botulinum produces various neurotoxins $(\mathrm{A}-\mathrm{H})$ with various effects depending on the target organs. Therefore, control of these pathogens using biological, chemical and physical agents can include effective roles in providing public health.

Nowadays, use of biologic agents in disease control is interested by researchers due to the adverse effects of drug use on general health (Hashempour-Baltork et al., 2019). One of the most important groups of the biological agents are associated with probiotic bacteria and their metabolites (Chugh and Kamal-Eldin, 2020). The World Health Organization (WHO) and Food and Agriculture Organization have considered probiotics as "live microorganisms when administered in adequate amounts confer a health benefit on the host"; hence, their health effects lead to improve or restore gut microbiota. These microorganisms are majorly bacteria of the Lactobacillus spp. and Bifidobacterium spp. (Verschuere et al., 2000). Recently, these microorganisms and their metabolites (e.g., bacteriocins) have broadly been used in food, pharmaceutical and medical industries due to safety (non-pathogenicity and antibiotic resistance), technological and functional (survival and viability during storage, persistence in gut tract and anti-inflammatory, anti-mutagenic and immunomodulation effects) characteristics (Hashempour-Baltork et al., 2019; Khezri et al., 2016, 2018; Verschuere et al., 2000). In addition, these microorganisms can be used to detoxify various compounds (mycotoxins, heavy metals and bacterial toxins) (Lam et al., 2016; Shetty and Jespersen, 2006; Zoghi et al., 2014). Therefore, the aim of this study is to review studies on inhibition of C. botulinum by probiotics bacteria and their metabolites.

\section{Probiotic Bacteria}

Probiotic means "for life" from the Greek "pro bios." Probiotics were famous by the Greeks and Romans with cheese and fermented dairy products (Soccol et al., 2010). Moreover, prebiotics are usually known as non-digestible food compounds (e.g., fibers, oligosaccharides, chicory root, garlic, leek, onion and banana) that are selectively used by gut microbiota for fermentation (Han et al., 2015). These compounds stimulate growth or activity of beneficial microorganisms. Furthermore, these bacteria linked to lucrative health after effects can specifically be targeted. Based on the literatures, prebiotics can alter gastrointestinal microbiota. However, it is not quite clear that how changes occur in the microbiota composition and performance by prebiotics, how stable these changes are and how these changes affect human health. Therefore, these characteristics need further investigations (Bäckhed et al., 2012). Nowadays, preparation of probiotics is chiefly based on lactic acid bacteria (LAB) (e.g., lactobacilli, streptococci and bifidobacteria) (Marhamatizadeh and Goosheh, 2016), which produce lactic acids by fermentation and metabolism of carbohydrates (Batra et al., 2019; Gezginc and Kara, 2019; Hayta and Ertop, 2019). Acceptable level of bacteria in probiotic products is up to $10^{7} \mathrm{CFU} / \mathrm{g}$ (Corcoran et al., 2006). However, the human gut must contain up to $10^{13}-10^{14}$ cells to ensure they reach the sufficient number caused by withstanding conditions and stresses (Savage, 1977). The major parts of the human GIT include their own distinct microbiota (Dethlefsen et al., 2006; Mills et al., 2011). Aerobic Gram-positive bacteria mostly inhabit stomach $\left(<10^{3} \mathrm{CFU} / \mathrm{g}\right)$. Lactobacillus, Bifidobacterium, Bacteroides and Streptococcus genera inhabit small intestine $\left(10^{3}-10^{4} \mathrm{CFU} / \mathrm{g}\right)$, and Bacteroides, Fusobacterium, Lactobacillus, Bifidobacterium and Eubacterium genera inhabit large intestine at large numbers $\left(10^{11}-10^{12}\right.$ $\mathrm{CFU} / \mathrm{g}$ ). The most popular probiotic microorganisms with claimed health benefits for humans and animals are represented in Figure 1 (Bintsis, 2018; Fijan, 2014; Kechagia et al., 2013; Soccol et al., 2010). These microorganisms have been isolated from various sources such as plants, fermented meat and dairy products, pickled fruits and vegetables, beverages, soy sauce, fish products and fermented cereal products.

Recently, researchers have shown that probiotic microorganisms are valuable in prohibition and treatment of various diseases and disorders. Nowadays, use of probiotics has increased intensely by growing awareness of the useful effects of these microorganisms and how these strains act in specific conditions (Gioacchini et al., 2011). It is noteworthy that these definitions are consistent with the definitions provided by WHO (Gioacchini et al., 2011; Postollec et al., 2011). Literatures on probiotics such as Lactobacillus usually concentrate on the interactions of 


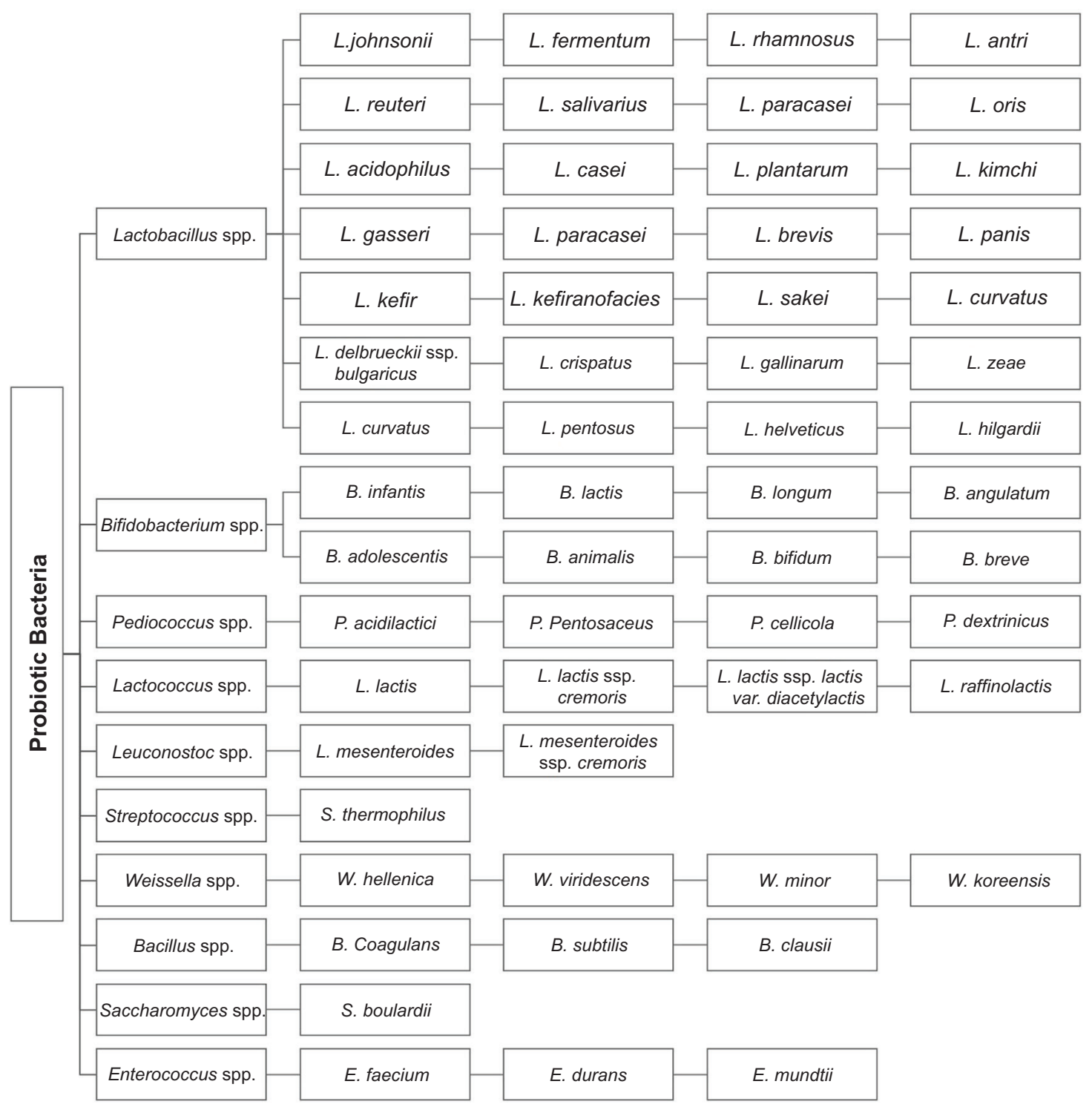

Figure 1. Probiotic microorganisms with claimed health benefits for humans and animals.

these bacteria with immune system (Durlu-Özkaya and Özkaya, 2011) and their effects as anticancer and bio-therapeutic agents. Probiotics include great potentials in treatment of disorders such as Helicobacter pylori infection and irritable bowel syndrome, as well as boosting immune systems of healthy individuals (Chapman et al., 2011; Dang et al., 2014; Moayyedi et al., 2010). The LAB such as bifidobacteria include good abilities of removing heavy metals (Bhakta et al., 2012), cyanotoxins (Oelschlaeger, 2010) and mycotoxins from aqueous solutions (Dalié et al., 2010).

\section{Action mechanisms of probiotic bacteria}

Probiotics may provide their beneficial health effects in three modes (Markowiak and Slizewska, 2017): (i) adjustment of the host defense system, including inherent and acquired immune systems, (ii) direct or indirect effects on other microorganisms, pathogens and commensals, and (iii) effects on metabolites of microorganisms such as toxins and on host products. Deactivating toxins and detoxifying host products and other food compounds in GIT may be carried out by various activities. Probiotics may use a dual effect for this purpose, preventing or decreasing colonization of pathogen microorganisms in the intestines (Hemarajata and Versalovic, 2013) or interacting with the gut-associated lymphoid tissues to inhibit inflammatory responses and reinforce their own tolerance to foods (Belkaid and Hand, 2014). Overall, major probiotic mechanisms of action include development of the epithelial barrier, enhancement of adhesion to intestinal mucosa and concomitant inhibition of pathogen adhesion, competitive exclusion of pathogenic microorganisms, production of anti-microorganism substances 

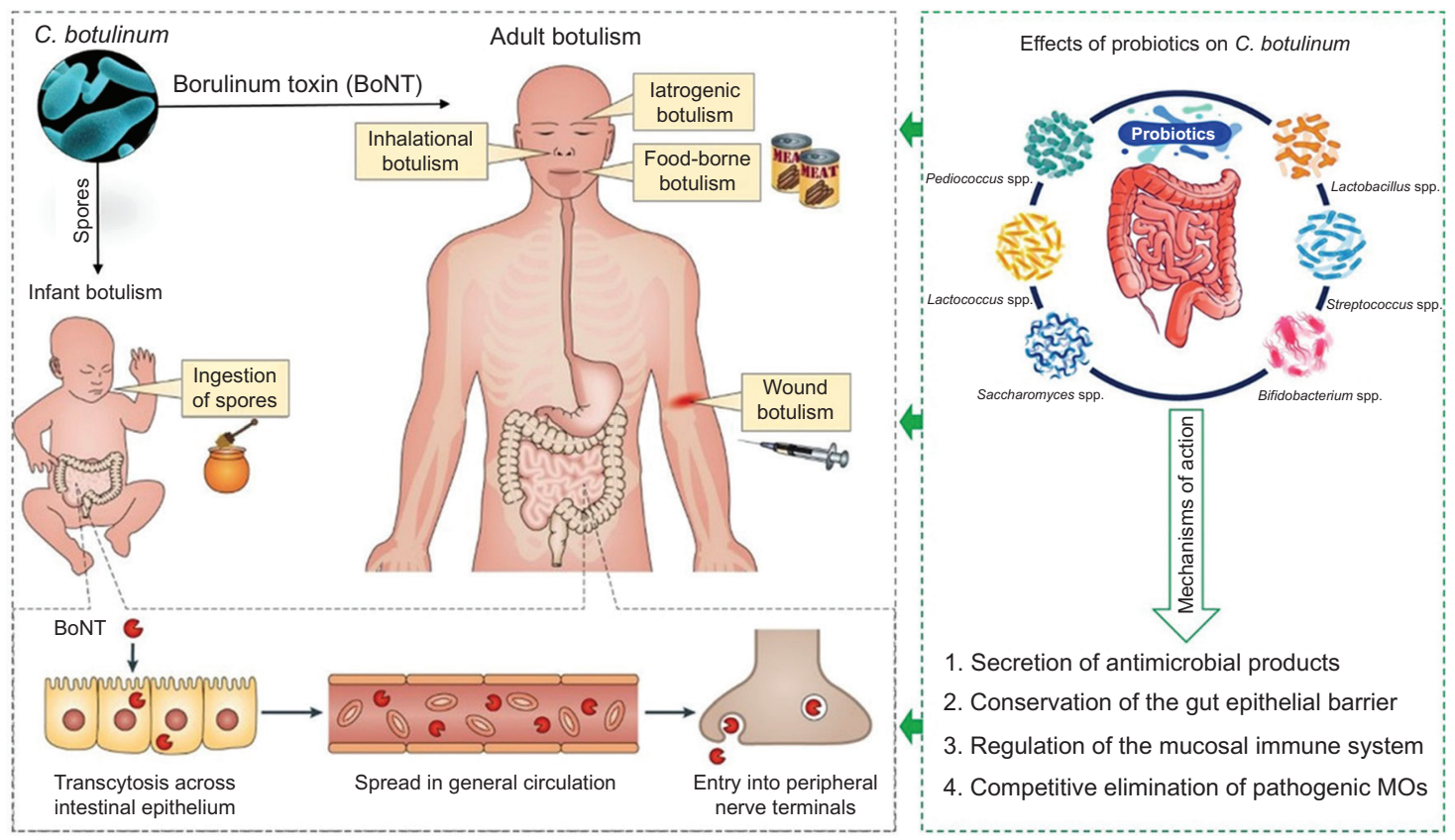

Figure 2. Mechanism action of probiotics bacteria in inhibition of Clostridium botulinum.

and modulation of the immune system (Plaza-Diaz et al., 2019) (Figure 2).

\section{Bacteriocins produced by probiotic bacteria}

Bacteriocins or probiotic metabolites are classified into four major groups based on their molecular mass, thermo-stability, enzymatic sensitivity, modified amino acids and mechanism of action (Chugh and KamalEldin, 2020). As presented in Table 1, several bacteriocins are described, which can be achieved by probiotic bacteria. Nisin, one of the most important bacteriocins, is the prototype lantibiotic (an amphipathic antibiotic peptide) from Lactococcus lactis and Streptococcus lactis (Figure 3a). As shown in Figure 3b, two inhibition or killing mechanisms of nisin are usually seen in bacterial cells. Nisin can bind to lipid II (located in the cell membrane and plays a fundamental role in cell wall synthesis), causing pore formation. The second mechanism is interfering and preventing the production of cell wall (Breukink and de Kruijff, 2006; Raybaudi-Massilia et al., 2009; Zhou et al., 2015).

\section{Clostridium botulinum and Its Neurotoxins}

Clostridium spp., anaerobic spore-forming bacteria, are widely found in nature, intestines of humans and animals and foodstuffs, especially fresh meats, drinks, milks and canned foods (Fooda, 2018). The C. botulinum spores are often found on the surfaces of fruits and vegetables and in seafood. The bacteria grow best under low-oxygen conditions, producing spores and toxins. The toxin is most commonly formed when foods are improperly processed (canned) at homes. These bacteria produce spores and are very resistant to heat. Of the various bacterial species, $C$. botulinum causes serious food poisoning disorders associated with meats, fishes and vegetables (Fooda, 2018). The C. botulinum strains are categorized into four major groups, depending on their toxin types and proteolytic abilities (Table 2). Group I consists of Type A and Type B proteolytic strains and is characterized as highly proteolytic, and Group II are non-proteolytic Type B and all Type E strains (Nadjafi and Hamzeh, 2017). The optimum and minimum temperature of growth for proteolytic strains include 37 and $10{ }^{\circ} \mathrm{C}$, respectively. Sodium chloride and nitrite at refrigeration temperatures synergistically affect $C$. botulinum spores, especially in cured meats (Alahakoon et al., 2015). The neurotoxin blocks releasing acetylcholine from the motor nerve endings, resulting in flaccid paralysis in humans and animals (Rossetto et al., 2014). The C. botulinum causes three major infections in humans, including foodborne botulism, infant botulism and wound botulism. The toxin is usually demolished by heating $\left(80^{\circ} \mathrm{C} / 20 \mathrm{~min}\right.$ or $\left.85^{\circ} \mathrm{C} / 5 \mathrm{~min}\right)$. In other hand, in a recent study conducted by Guo et al. (2020), they summarized the researches involved in benefits and potential risks of Clostridium species to our health, to develop Clostridium species as novel probiotics for human health and animal production. Up to now, Clostridium species have been reported to attenuate inflammation and allergic diseases effectively owing to their distinctive biological activities. Their cellular components and metabolites, such as butyrate, secondary bile acids and indolepropionic acid, play a probiotic role primarily through energizing 
Table 1. Some important bacteriocins produced by probiotic bacteria

\begin{tabular}{|c|c|c|}
\hline Producing Organism & Bacteriocins & References \\
\hline Lactobacillus curvatus & $\begin{array}{l}\text { Curvalicin a; Curvalicin b; Curvalicin c; Curvaticin FS47; Curvacin-A; } \\
\text { Curvaticin L442 }\end{array}$ & $\begin{array}{l}\text { Ghalfi et al., 2010; Hammami et al., } \\
\text { 2010; Nishant et al., } 2011\end{array}$ \\
\hline Lactobacillus acidophilus & Acidocin J1132 $\beta$; Acidocin B (AcdB); Acidocin 8912; Acidocin A & $\begin{array}{l}\text { Gillor et al., 2008; Hammami et al., } \\
\text { 2010; Nishant et al., } 2011\end{array}$ \\
\hline Lactococcus lactis & Bacteriocin J46; Nisin Q; Nisin F; Lacticin Z; Lacticin Q & $\begin{array}{l}\text { Hammami et al., 2010; Nishant et al., } \\
2011\end{array}$ \\
\hline $\begin{array}{l}\text { Lactococcus lactis subsp } \\
\text { (Streptococcus lactis) }\end{array}$ & $\begin{array}{l}\text { Lacticin } 481 \text { (Lactococcin DR); Nisin A; Lactococcin MMFII; Lacticin } \\
3147 \text { A2; Lacticin } 3147 \text { A1; Nisin Z; Lactococcin-G } \beta \text {; Lactococcin-G } \alpha \text {; } \\
\text { Lactococcin 972; LsbB }\end{array}$ & $\begin{array}{l}\text { Hammami et al., 2010; Nishant et al., } \\
2011\end{array}$ \\
\hline $\begin{array}{l}\text { Lactococcus lactis subsp } \\
\text { (Streptococcus cremoris) }\end{array}$ & Lactococcin-B; Lactococcin-A & $\begin{array}{l}\text { Hammami et al., 2010; Nishant et al., } \\
2011\end{array}$ \\
\hline Lactobacillus paracasei & Lactocin-705 & $\begin{array}{l}\text { Hammami et al., 2010; Nishant et al., } \\
2011\end{array}$ \\
\hline Lactobacillus plantarum & $\begin{array}{l}\text { Plantaricin S } \beta ; \text { Plantaricin C19; Plantaricin W } \alpha \text {; Plantaricin } 1.25 \beta \text {; } \\
\text { Plantaricin 163; Plantaricin-A; Plantaricin J; Plantaricin S } \alpha \text {; Plantaricin } \\
\text { K; Plantaricin E; Plantaricin F; Plantaricin NC8 } \alpha \text {; Plantaricin NC8 } \beta \text {; } \\
\text { Plantaricin 423; Plantaricin W } \beta \text {; Plantaricin ASM1; Glycocin F }\end{array}$ & $\begin{array}{l}\text { Hammami et al., 2010; Nishant et al., } \\
2011\end{array}$ \\
\hline Lactobacillus sakei & $\begin{array}{l}\text { Lactocin-S; Bavaricin-A; Sakacin-A; Sakacin-P (Sakacin 674); } \\
\text { Bavaricin-MN; Sakacin G }\end{array}$ & $\begin{array}{l}\text { Hammami et al., 2010; Nishant et al., } \\
2011\end{array}$ \\
\hline Lactobacillus amylovorus & Lactobin-A (Amylovorin-L471) & $\begin{array}{l}\text { Hammami et al., 2010; Nishant et al., } \\
2011\end{array}$ \\
\hline Lactobacillus johnsonii & Lactacin-F (lafA); Lactacin-F (lafX) & $\begin{array}{l}\text { Gillor et al., 2008; Nishant et al., } \\
2011\end{array}$ \\
\hline Lactobacillus reuteri & Reutericin & $\begin{array}{l}\text { Hammami et al., 2010; Nishant et al., } \\
2011\end{array}$ \\
\hline Lactobacillus salivarius & Bactofencin A; Bacteriocin L-1077 & $\begin{array}{l}\text { Gillor et al., 2008; Nishant et al., } \\
2011\end{array}$ \\
\hline Lactobacillus rhamnosus & Rhamnosin A & Hammami et al., 2010 \\
\hline Leuconostoc mesenteroides & Leucocin-B; Mesentericin Y105; Leucocin C; Leucocyclicin Q & $\begin{array}{l}\text { Hammami et al., 2010; Nishant et al., } \\
2011\end{array}$ \\
\hline Pediococcus acidilactici & Pediocin PA-1 (Pediocin ACH) & $\begin{array}{l}\text { Gillor et al., 2008; Hammami et al., } \\
2010\end{array}$ \\
\hline Weissella cibaria & Weissellicin 110 & Hammami et al., 2010 \\
\hline Escherichia coli & $\begin{array}{l}\text { Microcin J25; Microcin B17 (MccB17); Microcin H47; Colicin-V } \\
\text { (Microcin-V); Colicin-E1; Colicin-10; Colicin-N; Colicin-M; Colicin-la; } \\
\text { Colicin-Ib; Microcin-24; Microcin C7 }\end{array}$ & $\begin{array}{l}\text { Gillor et al., 2008; Hammami et al., } \\
2010\end{array}$ \\
\hline Enterococcus mundtii & Mundticin; Mundticin KS; Enterocin CRL35 (Mundticin KS); Mundticin L & Hammami et al., 2010 \\
\hline Enterococcus faecium & $\begin{array}{l}\text { Enterocin Q; Enterocin P; Enterocin 7A (Enterocin L50A); Enterocin } \\
\text { A; Enterocin B; Bacteriocin E50-52; Enterocin HF; Enterocin Xalpha; } \\
\text { Enterocin Xbeta; Enterocin K1; Bacteriocin T8 }\end{array}$ & $\begin{array}{l}\text { Gillor et al., 2008; Hammami et al., } \\
2010\end{array}$ \\
\hline Bacillus subtilis & Subpeptin JM4-B; Subtilin; Subtilosin-A; Sublancin 168; Subtilosin; LCl & $\begin{array}{l}\text { Gillor et al., 2008; Hammami et al., } \\
2010\end{array}$ \\
\hline Bacillus cereus & $\begin{array}{l}\text { Thiocillin (Micrococcin P1) (Micrococcin P2) (Thiocillin I) (Thiocillin } \\
\text { II) (Thiocillin III) (Thiocillin IV) (Antibiotic YM-266183) (Antibiotic } \\
\text { YM-266184); Cerein 7B }\end{array}$ & $\begin{array}{l}\text { Gillor et al., 2008; Hammami et al., } \\
2010\end{array}$ \\
\hline
\end{tabular}

intestinal epithelial cells, strengthening intestinal barrier and interacting with immune system. In turn, our diets and physical state of body can shape unique pattern of Clostridium species in gut. In view of their salutary performances, Clostridium species have a huge potential as probiotics. However, there are still some nonnegligible risks and challenges in approaching application of them (Guo et al., 2020).

\section{Effects of Probiotic Bacteria on Clostridium botulinum}

There are at least 7-8 various serotypes of $C$. botulinum neurotoxins; from which, four serotypes of A, B, E and $\mathrm{F}$ cause botulism in humans (Gonzalez-Escalona et al., 2014). The neurotoxins of C. botulinum are very dangerous for humans with the oral and parenteral and lethal 


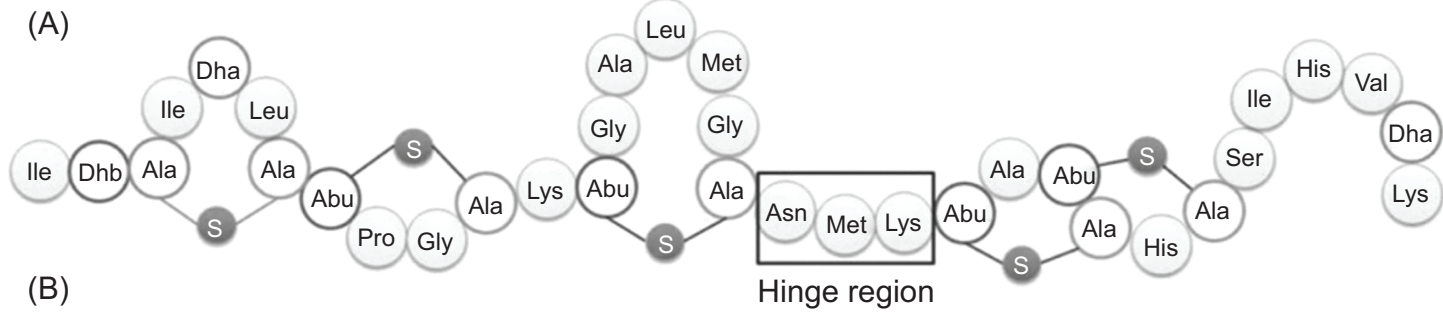

(B) Hinge region

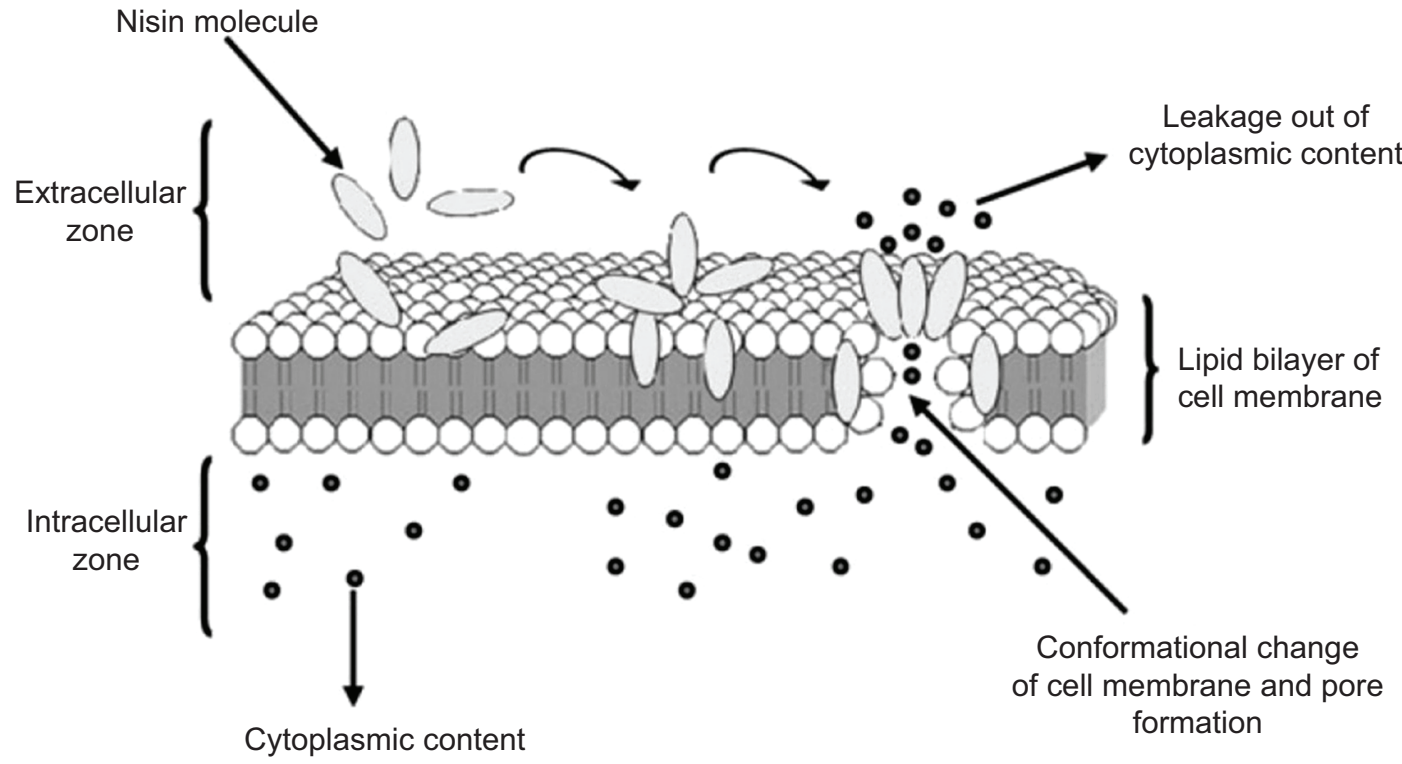

Figure 3. (A) Structure of nisin A. Dhb, dehydrobutyrine; Dha, dehydroalanine; Abu-S-Ala, $\beta$-methyllanthionine; Ala-S-Ala, lanthionine; Hinge region (Asn-Met-Lys) (42). (B) Mechanism of action of nisin in the cell of bacteria (45).

(other than intestinal canal) doses of $0.1-1 \mathrm{ng} / \mathrm{kg}$ and $1000 \mathrm{ng} / \mathrm{kg}$, respectively. Because of the toxin lethality, there is a considerable economic burden linked to the management of intoxication (Rummel, 2015; Tighe and Schiavo, 2013). The first function in botulinum neurotoxin defection and foodborne illnesses is surviving in GIT. Then, toxin should bind and insert to the intestinal epithelia to spread into the bloodstream. The probiotic mechanisms against pathogens include the following: (i) conservation of the gut-epithelial barrier, (ii) competitive elimination of pathogenic microorganisms, (iii) emission of antimicrobial metabolites and (iv) regulation of the mucosal immune system (Oelschlaeger, 2010; Salminen et al., 2010).

\section{Effects of Bacteriocins on Clostridium botulinum}

Bacteriocins include bacterial peptide toxins, which inhibit growth of similar or closely linked bacterial species. They vary structurally, functionally and biologically (Han et al., 2015). Activity of bacteriocins depends on the properties of food systems (Noordiana et al., 2013). Generally, pH less than 6.0 in low-fat and low-protein foods include the most effects on nisin (Chikindas et al., 2018). Use of bacteriocins as pathogen prevention agents is particularly interesting in components such as processed refrigerated meats. The $C$. botulinum is a great problem in minimally processed refrigerated meats because of its heat-resistant spores, which lead to production of toxins in foods at inappropriate temperatures (Bonsaglia et al., 2014; Kasalica et al., 2011). Several LAB include excellent abilities to produce bacteriocins for the inhibition of Listeria monocytogenes, C. botulinum and a wide range of foodborne pathogens (Gálvez et al., 2010; Reis et al., 2012). Indeed, C. botulinum is a nisin-resistant clostridial species (Zhou et al., 2014). In a relevant study, 23 LAB strains were assessed for bacteriocin-like activity against Types A and B spores from C. botulinum strains (Cizeikiene et al., 2013). Overall, Pediococcus pentosaceus ATCC 43200, P. pentosaceus ATCC 43201, L. lactic subsp. lactic ATCC 11454, L. acidophilus N2, L. plantarum Lb75, L. plantarum Lb592 and L. plantarum BN demonstrated bacteriocin-like prevention to all C. botulinum strains. Based on the minimum inhibitory concentration (MIC) assay, P. pentosaceus 43200 included the maximum inhibitory effects on C. botulinum (Dobson et al., 2012). Nisin is one of the most common bacteriocins, showing wide effects against Gram-positive bacteria 
Table 2. Abstract of C. botulinum strains and their toxins (Jay et al., 2005)

\begin{tabular}{|c|c|c|c|c|c|c|c|}
\hline Property & A & B & B & $E$ & $\mathrm{~F}$ & $\mathbf{F}$ & G \\
\hline Year discovered & 1904 & 1896 & 1960 & 1936 & 1960 & 1965 & 1969 \\
\hline P or NP & $P$ & $P$ & NP & NP & $P$ & NP & $\mathrm{P}$ (weak) \\
\hline Group & I & I & $\|$ & ॥ & I & II & IV \\
\hline Primary habitat & Terrestrial & Terrestrial & Aquatic & Aquatic & Aquatic & Aquatic & Terrestrial \\
\hline $\begin{array}{l}\text { Minimum growth } \\
\text { temp. }\left({ }^{\circ} \mathrm{C}\right)\end{array}$ & $\sim 10$ & $\sim 10$ & 3.3 & 3.3 & $\sim 10$ & 3.3 & $\sim 12$ \\
\hline $\begin{array}{l}\text { Maximum growth } \\
\text { temp. }\left({ }^{\circ} \mathrm{C}\right)\end{array}$ & $\sim 50$ & $\sim 50$ & $\sim 45$ & $\sim 45$ & $\sim 50$ & $\sim 45$ & n.d. \\
\hline $\begin{array}{l}\text { Minimum pH for } \\
\text { growth }\end{array}$ & 4.7 & 4.7 & 4.7 & 4.8 & 4.8 & 4.8 & 4.8 \\
\hline $\begin{array}{l}\text { Minimum aw for } \\
\text { growth }\end{array}$ & 0.94 & 0.94 & $\sim 0.97$ & $\sim 0.97$ & $0.94 ?$ & $\sim 0.97$ & n.d. \\
\hline $\begin{array}{l}\text { Thermal } D \text { values } \\
\text { for endospores }\left({ }^{\circ} \mathrm{C}\right)\end{array}$ & $\mathrm{D} 110=2.72-2.89$ & $\mathrm{D} 110=1.34-1.37$ & n.d. & $\mathrm{D} 80=0.80$ & $\mathrm{D} 110=1.45-1.82$ & D82.2 $=0.25-0.84$ & $\mathrm{D} 110=0.45-0.54$ \\
\hline $\begin{array}{l}\text { Radiation D values } \\
\text { of spores (kGy) }\end{array}$ & $1.2-1.5$ & $1.1-1.3$ & n.d. & 1.2 & $1.1 ; 2.5$ & 1.5 & n.d. \\
\hline $\begin{array}{l}\text { Maximum } \mathrm{NaCl} \text { for } \\
\text { growth (\%) }\end{array}$ & $\sim 10$ & $\sim 10$ & $5-6$ & $5-6$ & $8-10$ & $5-6$ & n.d. \\
\hline $\begin{array}{l}\text { Relative frequency } \\
\text { of food outbreaks }\end{array}$ & High & High & n.d. & High (seafood) & 1 outbreak & 1 outbreak & None \\
\hline $\mathrm{H}_{2} \mathrm{~S}$ production & + & + & - & - & + & - & ++ \\
\hline Casein hydrolysis & + & + & - & - & + & - & + \\
\hline Lipase production & + & + & + & + & + & + & - \\
\hline Glucose fermentation & + & + & + & + & + & + & - \\
\hline Mannose fermentation & - & - & + & + & - & + & - \\
\hline Propionic acid produced & + & + & n.d. & n.d. & + & n.d. & n.d. \\
\hline
\end{tabular}

Note: $\mathrm{P}=$ proteolytic; $\mathrm{NP}=$ non-proteolytic; + = positive; ++ = strongly positive; - = negative; n.d. = no data.

(Fernández-Pérez et al., 2018). Nisin is "generally recognized as safe" (GRAS) to prevent C. botulinum spores. Synergistic effects of nisin and heating on C. botulinum have previously been demonstrated by Gao and Ju (2008). Literatures have described that various types of $C$. botulinum strains include various resistances to nisin; however, results may be controversial (Chung and Yousef, 2007). Furthermore, growth condition and food components affect nisin efficiency. Low-acid environments, short heat-shocking periods, high spore loads, high protein and phospholipid concentrations and increased incubation temperatures can decrease nisin ability to inhibit C. botulinum growth (Gharsallaoui et al., 2016).

\section{Conclusion}

Considering the importance of pathogenicity and the mortality rate of $C$. botulinum, control of the bacterial growth and its neurotoxin production is critically important due to food safety aspects. Probiotics and their bacteriocins, as biological control agents, play significant roles in detoxification and decrease of the risk by these pathogens. The antagonism between C. botulinum and bacterial members of the ecosystems is well known. Reports have revealed that use of probiotics and their metabolites can help inhibit C. botulinum colonization and decrease its neurotoxin production. Proteolytic and non-proteolytic types of C. botulinum show similar reactions to inhibitory effects of probiotics in foodstuffs. However, matrices of the foods include great effects on action mechanisms of nisin. The major affecting factors on potency of nisin to prevent C. botulinum growth include $\mathrm{pH}$, heat-shocking periods, spore loads, protein and phospholipid contents and environmental temperatures.

\section{Acknowledgments}

This study is related to the project NO. 1397/68940 from Student Research Committee, Shahid Beheshti University of Medical Sciences, Tehran, Iran. We also appreciate the "Student Research Committee" and "Research \& 
Technology Chancellor" in Shahid Beheshti University of Medical Sciences for their financial support of this study.

\section{Disclosure statement}

No potential conflict of interest was reported by the authors.

\section{References}

Alahakoon, A.U., Jayasena, D.D., Ramachandra, S. and Jo, C., 2015. Alternatives to nitrite in processed meat: up to date. Trends in Food Science \& Technology 45: 37-49. https://doi.org/10.1016/j. tifs.2015.05.008

Bäckhed, F., Fraser, C.M., Ringel, Y., Sanders, M.E., Sartor, R.B., Sherman, P.M., et al., 2012. Defining a healthy human gut microbiome: current concepts, future directions, and clinical applications. Cell Host \& Microbe 12: 611-622. https://doi. org/10.1016/j.chom.2012.10.012

Batra, V., Ghosh, M. and Ganguli, A., 2019. A simple fermentative process for ensuring safety and nutrition of legume and legume wheat based sourdoughs. Quality Assurance and Safety of Crops \& Foods 11: 639-645. https://doi.org/10.3920/QAS2018.1421

Belkaid, Y. and Hand, T.W., 2014. Role of the microbiota in immunity and inflammation. Cell 157(1), 121-141. https://doi. org/10.1016/j.cell.2014.03.011

Bhakta, J., Ohnishi, K., Munekage, Y., Iwasaki, K. and Wei, M., 2012. Characterization of lactic acid bacteria-based probiotics as potential heavy metal sorbents. Journal of Applied Microbiology 112: 1193-1206. https://doi. org/10.1111/j.1365-2672.2012.05284.x

Bintsis, T., 2018. Lactic acid bacteria: their applications in foods. Journal of Bacteriology \& Mycology 6: 89-94. https://doi. org/10.15406/jbmoa.2018.06.00182

Bonsaglia, E., Silva, N., Júnior, A.F., Júnior, J.A., Tsunemi, M. and Rall, V., 2014. Production of biofilm by Listeria monocytogenes in different materials and temperatures. Food Control 35: 386-391. https://doi.org/10.1016/j.foodcont.2013.07.023

Breukink, E. and de Kruijff, B., 2006. Lipid II as a target for antibiotics. Nature Reviews Drug Discovery 5: 321. https://doi. org/10.1038/nrd2004

Butel, M.-J., 2014. Probiotics, gut microbiota and health. Médecine et maladies infectieuses 44: 1-8. https://doi.org/10.1016/j. medmal.2013.10.002

Chapman, C., Gibson, G.R. and Rowland, I., 2011. Health benefits of probiotics: are mixtures more effective than single strains? European Journal of Nutrition 50: 1-17. https://doi.org/10.1007/ s00394-010-0166-Z

Chikindas, M.L., Weeks, R., Drider, D., Chistyakov, V.A. and Dicks, L.M., 2018. Functions and emerging applications of bacteriocins. Current Opinion in Biotechnology 49: 23-28. https:// doi.org/10.1016/j.copbio.2017.07.011

Chugh, B. and Kamal-Eldin, A., 2020. Bioactive compounds produced by probiotics in food products. Current Opinion in
Food Science 32: 76-82. https://doi.org/10.3746/jfn.2007.12. 4.259

Chung, Y.K. and Yousef, A.E., 2007. Effect of nisin against Clostridium botulinum during spore-to-cell transformation. Preventive Nutrition and Food Science 12(4): 259-266.

Cizeikiene, D., Juodeikiene, G., Paskevicius, A. and Bartkiene, E., 2013. Antimicrobial activity of lactic acid bacteria against pathogenic and spoilage microorganism isolated from food and their control in wheat bread. Food Control 31: 539-545. https://doi. org/10.1016/j.foodcont.2012.12.004.

Corcoran, B., Ross, R., Fitzgerald, G., Dockery, P. and Stanton, C., 2006. Enhanced survival of GroESL-overproducing Lactobacillus paracasei NFBC 338 under stressful conditions induced by drying. Applied and Environmental Microbiology 72: 5104-5107. https://doi.org/10.1128/AEM.02626-05

Dalié, D., Deschamps, A. and Richard-Forget, F., 2010. Lactic acid bacteria-potential for control of mould growth and mycotoxins: a review. Food Control 21: 370-380. https://doi.org/10.1016/j. foodcont.2009.07.011

Dang, Y., Reinhardt, J.D., Zhou, X. and Zhang, G., 2014. The effect of probiotics supplementation on Helicobacter pylori eradication rates and side effects during eradication therapy: a meta-analysis. PLoS One 9: e111030. https://doi.org/10.1371/journal. pone. 0111030

Dethlefsen, L., Eckburg, P.B., Bik, E.M. and Relman, D.A., 2006. Assembly of the human intestinal microbiota. Trends in Ecology \& Evolution 21: 517-523. https://doi.org/10.1016/j.tree.2006.06.013

Dobson, A., Cotter, P.D., Ross, R.P. and Hill, C., 2012. Bacteriocin production: a probiotic trait? Applied and Environmental Microbiology 78: 1-6. https://doi.org/10.1128/AEM.05576-11

Donaldson, G.P., Lee, S.M. and Mazmanian, S.K., 2016. Gut biogeography of the bacterial microbiota. Nature Reviews Microbiology 14: 20. https://doi.org/10.1038/nrmicro3552

Durlu-Özkaya, F. and Özkaya, M.T., 2011. Oleuropein using as an additive for feed and products used for humans. Journal of Food Processing and Technology 2(3): 113. https://doi. org/10.4172/2157-7110.1000113

Eslami, P., Forootan, K., Davarpanah, L. and Vahabzadeh, F., 2020. Incorporation of Lactobacillus casei into the inner phase of the water-in-oil-in-water (W1/O/W2) emulsion prepared with $\beta$-cyclodextrin and bacterial survival in a model gastric environment. Applied Food Biotechnology 7: 171-182.

Fernández-Pérez, R., Sáenz, Y., Rojo-Bezares, B., Zarazaga, M., Rodríguez, J.M., Torres, C., et al., 2018. Production and antimicrobial activity of nisin under enological conditions. Frontiers in Microbiology 9: 1918. https://doi.org/10.3389/fmicb.2018.01918

Fijan, S., 2014. Microorganisms with claimed probiotic properties: an overview of recent literature. International Journal of Environmental Research and Public Health 11: 4745-4767. https://doi.org/10.3390/ijerph110504745

Fooda, 2018. Food poisoning with Clostridium botulinum. http:// fooda.ir.

Gálvez, A., Abriouel, H., Benomar, N. and Lucas, R., 2010. Microbial antagonists to food-borne pathogens and biocontrol. Current Opinion in Biotechnology 21: 142-148. https://doi. org/10.1016/j.copbio.2010.01.005 
Gao, Y.L. and Ju, X.R., 2008. Exploiting the combined effects of high pressure and moderate heat with nisin on inactivation of Clostridium botulinum spores. Journal of Microbiological Methods 72(1): 20-28. https://doi.org/10.1016/j.mimet.2007.11.003

Gezginc, Y. and Kara, Ü., 2019. The effect of exopolysaccharide producing Lactobacillus plantarum strain addition on sourdough and wheat bread quality. Quality Assurance and Safety of Crops \& Foods 11: 95-106. https://doi.org/10.3920/QAS2018.1361

Gharsallaoui, A., Oulahal, N., Joly, C. and Degraeve, P., 2016. Nisin as a food preservative: part 1: physicochemical properties, antimicrobial activity, and main uses. Critical Reviews in Food Science and Nutrition 56(8): 1262-1274. https://doi.org/10.108 0/10408398.2013.763765

Gioacchini, G., Lombardo, F., Merrifield, D., Silvi, S., Cresci, A., Avella, M. et al., 2011. Effects of probiotics on Zebrafish reproduction. Journal of Aquaculture Research and Development S1-S6. https://doi.org/10.4172/2155-9546.S1-002

Gonzalez-Escalona, N., Thirunavukkarasu, N., Singh, A., Toro, M., Brown, E.W., Zink, D., Rummel, A. et al., 2014. Draft genome sequence of bivalent Clostridium botulinum strain IBCA107060, encoding botulinum neurotoxin B and a new FA mosaic type. Genome Announcements 2: e01275-01214. https://doi. org/10.1128/genomeA.01275-14

Guo, P., Zhang, K., Ma, X. and He, P., 2020. Clostridium species as probiotics: potentials and challenges. Journal of Animal Science and Biotechnology 11(1): 1-10. https://doi.org/10.1186/ s40104-019-04.02-1

Han, J., Chen, D., Li, S., Li, X., Zhou, W.-W., Zhang, B., et al., 2015. Antibiotic susceptibility of potentially probiotic Lactobacillus strains. Italian Journal of Food Science 27: 282-289.

Hashempour-Baltork, F., Hosseini, H., Shojaee-Aliabadi, S., Torbati, M., Alizadeh, A.M. and Alizadeh, M., 2019. Drug resistance and the prevention strategies in food Borne bacteria: an update review. Advanced Pharmaceutical Bulletin 9: 335. https://doi.org/10.15171/apb.2019.041

Hayta, M. and Ertop, M.H., 2019. Physicochemical, textural and microbiological properties of optimised wheat bread formulations as affected by differently fermented sourdough. Quality Assurance and Safet y of Crops \& Foods 11: 283-293. https:// doi.org/10.3920/QAS2018.1387

Hemarajata, P. and Versalovic, J., 2013. Effects of probiotics on gut microbiota: mechanisms of intestinal immunomodulation and neuromodulation. Therapeutic Advances in Gastroenterology 6(1), 39-51. https://doi.org/10.1177/1756283X 12459294

Jay, J.M., Loessner, M.J. and Golden, D.A., 2005. Modern food microbiology. Springer US, New York, 790 pp.

Kasalica, A., Vuković, V., Vranješ, A., and Memiši, N., 2011. Listeria monocytogenes in milk and dairy products. Biotechnology in Animal Husbandry 27 (3). Doi:10.2298/BAH1103067K

Kechagia, M., Basoulis, D., Konstantopoulou, S., Dimitriadi, D., Gyftopoulou, K., Skarmoutsou, N., et al., 2013. Health benefits of probiotics: a review. ISRN Nutrition 2013. https://doi. org/10.5402/2013/481651

Khaneghah, A.M., Abhari, K., Eş, I., Soares, M.B., Oliveira, R.B., Hosseini, H., et al., 2020. Interactions between probiotics and pathogenic microorganisms in hosts and foods: a review. Trends in Food Science \& Technology 95: 205-218. https://doi. org/10.1016/j.tifs.2019.11.022

Khezri, S., Dehghan, P., Mahmoudi, R. and Jafarlou, M., 2016. Fig juice fermented with lactic acid bacteria as a nutraceutical product. Pharmaceutical Sciences 22: 260-266. https://doi. org/10.15171/PS.2016.40

Khezri, S., Mahmoudi, R. and Dehghan, P., 2018. Fig juice fortified with inulin and Lactobacillus Delbrueckii: a promising functional food. Applied Food Biotechnology 5: 97-106.

Lam, T.I., Tam, C.C., Stanker, L.H. and Cheng, L.W., 2016. Probiotic microorganisms inhibit epithelial cell internalization of botulinum neurotoxin serotype A. Toxins 8: 377. https://doi. org/10.3390/toxins 8120377

Marhamatizadeh, M.H. and Goosheh, S.R., 2016. The combined effect of Thymus vulgaris extract and probiotic bacteria (Lactobacillus acidophyllus and Bifidubacterium bifidum) on aflatoxin $\mathrm{m} 1$ concentration in kefir beverage. Italian Journal of Food Science 28: 517.

Markowiak, P. and Śliżewska, K., 2017. Effects of probiotics, prebiotics, and synbiotics on human health. Nutrients 9(9): 1021. https://doi.org/10.3390/nu9091021

Mills, S., Stanton, C., Fitzgerald, G.F. and Ross, R., 2011. Enhancing the stress responses of probiotics for a lifestyle from gut to product and back again, Microbial cell factories. BioMed Central S19. https://doi.org/10.1186/1475-2859-10-S1-S19

Moayyedi, P., Ford, A.C., Talley, N.J., Cremonini, F., FoxxOrenstein, A.E., et al., 2010. The efficacy of probiotics in the treatment of irritable bowel syndrome: a systematic review. Gut 59: 325-332. https://doi.org/10.1136/gut.2008.167270

Nadjafi, M. and Hamzeh, P.S., 2017. Botulinum neurotoxins, a real bioterrorism threat: a classic review. Nurse and Physician Within War 13.

Nishant, T., Sathish, K., Arun, K., Hima, B. and Raviteja, Y., 2011. Bacteriocin producing probiotic lactic acid bacteria. Journal of Microbial and Biochemical Technology 3: 5.

Noordiana, N., Fatimah, A. and Mun, A., 2013. Antibacterial agents produced by lactic acid bacteria isolated from Threadfin Salmon and Grass Shrimp. International Food Research Journal 20(1): $117-124$.

Oelschlaeger, T.A., 2010. Mechanisms of probiotic actions-a review. International Journal of Medical Microbiology 300: 57-62. https://doi.org/10.1016/j.ijmm.2009.08.005

Plaza-Diaz, J., Ruiz-Ojeda, F.J., Gil-Campos, M. and Gil, A., 2019. Mechanisms of action of probiotics. Advances in Nutrition 10: S49-S66. https://doi.org/10.1093/advances/nmy063

Postollec, F., Falentin, H., Pavan, S., Combrisson, J. and Sohier, D., 2011. Recent advances in quantitative PCR (qPCR) applications in food microbiology. Food Microbiology 28: 848-861. https:// doi.org/10.1016/j.fm.2011.02.008

Raybaudi-Massilia, R.M., Mosqueda-Melgar, J., Soliva-Fortuny, R. and Martín-Belloso, O., 2009. Control of pathogenic and spoilage microorganisms in fresh-cut fruits and fruit juices by traditional and alternative natural antimicrobials. Comprehensive Reviews in Food Science and Food Safety 8: 157-180. https:// doi.org/10.1111/j.154.1-4337.2009.00076.x 
Reis, J., Paula, A., Casarotti, S. and Penna, A., 2012. Lactic acid bacteria antimicrobial compounds: characteristics and applications. Food Engineering Reviews 4: 124-140. https://doi.org/10.1007/ s12393-012-9051-2

Rossetto, O., Pirazzini, M. and Montecucco, C., 2014. Botulinum neurotoxins: genetic, structural and mechanistic insights. Nature Reviews Microbiology 12: 535. https://doi.org/10.1038/ nrmicro3295

Rummel, A., 2015. The long journey of botulinum neurotoxins into the synapse. Toxicon 107: 9-24. https://doi.org/10.1016/j. toxicon.2015.09.009

Sadrizadeh, N., Khezri, S., Dehghan, P. and Mahmoudi, R., 2018. Antibacterial effect of Teucrium polium essential oil and Lactobacillus casei probiotic on Escherichia coli O157: H7 in Kishk. Applied Food Biotechnology 5: 131-140.

Salminen, S., Nybom, S., Meriluoto, J., Collado, M.C., Vesterlund, S. and El-Nezami, H., 2010. Interaction of probiotics and pathogens-benefits to human health? Current Opinion in Biotechnology 21: 157-167. https://doi.org/10.1016/j. copbio.2010.03.016

Sánchez, B., Delgado, S., Blanco-Míguez, A., Lourenço, A., Gueimonde, M. and Margolles, A., 2017. Probiotics, gut microbiota, and their influence on host health and disease. Molecular Nutrition \& Food Research 61: 1600240. https://doi. org/10.1002/mnfr.201600240

Savage, D.C., 1977. Microbial ecology of the gastrointestinal tract. Annual Reviews in Microbiology 31: 107-133. https://doi. org/10.1146/annurev.mi.31.100177.000543

Shetty, P.H. and Jespersen, L., 2006. Saccharomyces cerevisiae and lactic acid bacteria as potential mycotoxin decontaminating agents. Trends in Food Science and Technology 17: 48-55. https://doi.org/10.1016/j.tifs.2005.10.004

Soccol, C.R., de Souza Vandenberghe, L.P., Spier, M.R., Medeiros, A.P., Yamaguishi, C.T., De Dea Lindner, J., et al., 2010. The potential of probiotics: a review. Food Technology and Biotechnology 48: 413-434.

Tighe, A.P. and Schiavo, G., 2013. Botulinum neurotoxins: mechanism of action. Toxicon 67: 87-93. https://doi.org/10.1016/j. toxicon.2012.11.011

Verschuere, L., Rombaut, G., Sorgeloos, P. and Verstraete, W., 2000. Probiotic bacteria as biological control agents in aquaculture. Microbiology and Molecular Biology Reviews 64: 655-671. https://doi.org/10.1128/MMBR.64.4.655-671.2000

Zendeboodi, F., Khorshidian, N., Mortazavian, A.M. and da Cruz, A.G., 2020. Probiotic: conceptualization from a new approach. Current Opinion in Food Science. 32: 103-123. https://doi.org/10.1016/j.cofs.2020.03.009

Zhou, H., Fang, J., Tian, Y. and Lu, X.Y., 2014. Mechanisms of nisin resistance in Gram-positive bacteria. Annals of Microbiology 64: 413-420. https://doi.org/10.1007/s13213-013-0679-9

Zhou, L., van Heel, A.J. and Kuipers, O.P., 2015. The length of a lantibiotic hinge region has profound influence on antimicrobial activity and host specificity. Frontiers in Microbiology 6: 11 . https://doi.org/10.3389/fmicb.2015.00011

Zoghi, A., Khosravi-Darani, K. and Sohrabvandi, S., 2014. Surface binding of toxins and heavy metals by probiotics. Mini Reviews in Medicinal Chemistry 14: 84-98. https://doi.org/10.2174/1389 557513666131211105554 